jlasic@ffst.hr

ORCID: 0000-0001-5254-7903

\title{
Ptica u hrvatskome prezimenskome mozaiku
}

\begin{abstract}
Lasić Josip, Ptica u hrvatskome prezimenskome mozaiku (Bird-related Component of Croatian Surnames). "Poznańskie Studia Slawistyczne" 20. Poznań 2021. Publishing House of the Poznan Society for the Advancement of the Arts and Sciences, Adam Mickiewicz University, pp. 123-139. ISSN 2084-3011.
\end{abstract}

Findings of the previous research suggest that, although the first records of surnames on the territory of the contemporary Republic of Croatia date back to the $12^{\text {th }}$ century, it is with the Council of Trent (1545-1563) that they became increasingly and extensively used (Frančić, 2015, 229). As far as contemporary surnames are concerned, their structure is regarded to be well established and easily detectable. Their frequency and distribution have also been the topics of much of previous research. Namely, the 2011 census showed that over thirty-three thousand surnames were registered in the Republic of Croatia. For the purposes of this paper, a group of surnames with a bird-related component - ornithonyms - has been singled out from the abovementioned list. The analysed corpus, consisting of approximately three hundred surnames with a component related to bird species, subspecies of groups, is of particular importance since, due to a number of linguistic and non-linguistic obstacles to the creation of a unique "bird" corpus, this interesting group of Croatian surnames has not been sufficiently described by Croatian linguists so far.

KeYwords: Croatian surnames; zoonims; ornithonym; bird species; genus of birds

\section{Uvod}

Antroponimija je tradicionalno u lingvistici definirana kao područje u okviru onomastike koje se bavi proučavanjem osobnih imena, prezimena i nadimaka. Izdvajajući prezimena, a promatrajući ih pritom s etimološkoga aspekta, dosadašnja su istraživanja potvrdila kako su kroz prošlost nastajala od osobnih imena, nadimaka, zanimanja, karakternih i kakvih drugih osobina čovjeka, zatim od geografskoga porijekla, ali i od naziva životinjskih vrsta i rodova (Putanec, Šimunović, 1976; Šimunović, 2006). Danas je najveći broj prezimena antroponimskoga postanja (tipovi prezimena Horvat, 
Jurić, Perić i sl.), dok su prezimena postala od zoonima (životinjskih naziva i vrsta) slabije zastupljena. Određivanje postanka pojedinoga prezimena nailazi ponekad na svojevrsne prepreke jer je za neka prezimena teško odrediti njihov postanak najčešće zbog nepoznavanja okolnosti i vremena kada su nastajali. U tim situacijama često nije moguće posve pouzdano utvrditi jesu li prezimena zoonimskoga ili antroponimskoga postanja ${ }^{1}$. Brojnost se pak prezimena antroponimskoga postanja u odnosu na podzastupljenost zoonimskih prezimena može dijelom opravdati i time što su u prošlosti pojedini nazivi životinja bili neprimjereni da bi motivirali postanak prezimena. Nazivi za životinjske vrste kao vol, tele ili u hrvatskim dijalektima zabilježene vrste svinče, cucek ili sraka zbog niza se pejorativnih konteksta rijetko susreću u etimologiji i u oblicima hrvatskih prezimena. Ne znači to kako zoonimskih prezimena nema. Naprotiv, krene li se promatrati unutar prezimena određena, konkretna životinjska vrsta, izdvaja se skupina ornitonima ${ }^{2}$. U bogatoj su tronarječnoj tradiciji hrvatskoga jezika ornitonimi vrlo zanimljivi i reprezentativni u onim prezimenima kroz čiji se sadržaj ogledaju nazivi i vrste ptica. U radu se raspravlja o hrvatskim prezimenima s ornitonimom u sastavu, a za početak se predstavlja interdisciplinaran pogled na definiranje i klasifikaciju pojma ornitonim. Uzima se opis uvriježen u području biologije i genetike životinjskoga svijeta. Prikaz podjele ptica kroz njezin biološki opis pokazao se nužnim zbog kasnijega predstavljanja postupka pri izradi predmeta istraživanja - izrađenoga korpusa prezimena s ornitonimom u sastavu.

\section{Ornitologija iz aspekta zoologije: red je naziv, a rod je vrsta}

Prema definiciji koju donosi Hrvatska enciklopedija $a^{3}$ ornitologija je znanstveno područje zoologije koje se bavi proučavanjem ptica $^{4}$, njihovim

${ }^{1}$ Primjerice hrvatska prezimena: Koza, Grlica, Zec, za koje se ne može pouzdano tvrditi jesu li antroponimskoga ili zoonimskoga postanja.

${ }^{2}$ Cf. ornitonim - zoonim koji obuhvaća ptičji naziv i ptičju vrstu i ornitologija - grana zoologije koja se bavi proučavanjem ptica, njihovim podrijetlom, građom, načinom života i sistematikom. U radu se dalje koristi ornitonim, množinski oblik je ornitonimi, a u smislu nadpojma za mnogobrojne nazive ptice prema njihovome redu, rodu i vrsti pripadanja.

${ }^{3}$ Detaljno na: https://www.enciklopedija.hr/Natuknica.aspx?ID=45576. 22.10.2020.

${ }^{4} \mathrm{Na}$ prostoru RH od 1901. godine djeluje Zavod za ornitologiju pri HAZU-u, što potvrđuje važnost proučavanja i očuvanja ptičjega svijeta. Više na: http://info.hazu.hr/hr/oakademiji/jedinice/zavod_za_ornitologiju. 22.10.2020. 
podrijetlom, građom, načinom života i sistematikom, a ptica je (lat. aves) razred dvonožnih, toplokrvnih kralješnjaka koji polažu jaja i tijekom vremena jure evoluirala je od nekadašnjega dinosaura iz podreda Therapoda. Varira danas veličinom od sitnoga kolibrija do krupnoga noja 5 .

Za potrebe je osnovnoga razvrstavanja i kasnijega opisa hrvatskih prezimena s ornitonimom u strukturi važno istaknuti dva elementa koji utječu na postanak takvih prezimena: geografska raznolikost i biološka raznolikost ptičjega svijeta. Danas u svijetu postoji između devet i deset tisuća poznatih vrsta pa je brojnošću ptica najraznovrsniji razred među kopnenim kralješnjacima (Batašić, 2012). Brojnost je životinjskoga svijeta ptice otežala postupak izrade istraživačkoga korpusa prezimena s ornitonimom u sastavu i stoga se u nastavku donosi kratak opis koji je prethodio stvaranju korpusa. Važno je to istaknuti jer se pokazalo da je svijet ptica, kao najraznovrsniji životinjski kopneni svijet, isprepleten nizom ,ptičjih” obilježja iz kojih se granaju daljnje podjele kao primjerice: red, rod, svojstvo, vrsta, naziv, rijetka ptica, domaća ptica, nedomaća ptica i dr.

Unatoč brojnosti i nepreglednosti vrsta i podvrsta, istraživački je korpus (v. dodatak 1) izrađen prema jasnome kriteriju - vidljivosti tzv. ptičjega apelativa u prezimenskome fondu Republike Hrvatske.

\subsection{Vrste i rodovi u pokušaju oblikovanja korpusa ornitonimskih prezimena}

U Republici je Hrvatskoj zabilježeno tristo devedeset (390) vrsta pti$\mathrm{ca}^{6}$. Raspoređene su u dvadeset (20) rodova, a novija je podjela zasnovana

${ }^{5}$ Detaljno na: http://datazone.birdlife.org/home. 22.10.2020.

${ }^{6}$ Pojedini autori svrstavaju ih u različite rodovske skupine (rodove) prema morfološko-anatomskim i biološkim svojstvima, a Lukač (2007, 5-10) objašnjava rodove i redove u uvodnome dijelu Popisa ptica Hrvatske: ,danas je prihvaćena tzv. taksonomska podjela prema Moron, Bock, Farrandovoj podjeli (1975) koja predviđa unutar roda ptica dvadest i pet (25) redova, a kasnija će se podjela nastala prema Sibleyu i Ahlquistu (1995) temeljiti na biokemijskoj analizi stupnja sličnosti i različitosti DNK koja predviđa dvadeset i dva (22) reda". Najveći su red unutar roda vrapčarke (hrv. pjevice; lat. Passeriformes) te dalje poznati ostali redovi: nojevke (Struthioniformes), rodarice (Ciconiiformes), guščarice (Anseriformes) i dr. Hrvatska je ornitofauna bogata i raznolika te se dijeli na gnijezdeće i negnijezdeće redove s podredovima (Krnjeta, 2003). 
prema ptičjim svojstvima. S obzirom na svojstva razlikuje se među pticama sljedeće: 1) red (ordo); 2) porodica (familia); 3) rod (genus); 4) vrsta (species); 5) podvrsta (subspecies).

Izradi se korpusa hrvatskih prezimena s ornitonimom krenulo od predložene podjele na redove (ordo) i rodove (genus). Red je tako za potrebe onomastičke klasifikacije postao (ptičji) naziv s nizom rodova koji su postali (ptičja) vrsta. Međutim, izrada se popisa s obzirom na ptičji naziv i ptičju vrstu pokazala neizvedivom zato što je biološka podjela klasificirana kroz dvadeset (20) ptičjih vrsta: cjevonosnice $^{7}$, dijetovke, gnjurci, golubovke, guščarice, kokoške ${ }^{8}$, kukavice, močvarice, pelikanke, plamenci, plijenori $^{9}$, rodarice, sadže, smrdovrane, sokolovke, sovovke, srpokrilke, širokljunke, vrapčarke $e^{10} \mathrm{i} \check{z}$ dralovke. Iz dvadeset je vrsta u biologiji i genetici ptičjega svijeta nastao niz novih podjela na ptičje podvrste.

Brojnost vrsta i podvrsta unutar krovnoga naziva ptica onemogućila je izradu jedinstvenoga korpusa za analizu prezimena s ornitonimskom sastavnicom. Uz to, dodatnu je nemogućnost stvaranja korpusa stvorila još jedna podjela ptica koja se odnosi na prostor Republike Hrvatske prema kojoj se one dijele na: gnjezdarice ${ }^{11}$, selice, zimovalice i ugrožene vrste. Jasno, kao i u drugim podjelama, i iz ove se klasifikacije kasnije izvodi niz podvrsta.

${ }^{7} \mathrm{U}$ RH su unutar reda cjevonosnica rodovi: burnica, zovoja i gregula.

${ }^{8}$ Red kokoški dijeli se na čak šezdeset i pet (65) rodova (vrsta) s više od dvije stotine podrodova (podvrsta). Upravo je ta brojnost rodova i vrsta otegotna okolnost pri izradi korpusa prezimena s ornitonimom u strukturi. Više o rodovima i redovima kokoški na: https:// www.bionet-skola.com/w/Koko\%C5\%A1i. 22.10.2020.

${ }^{9}$ Red plijenora dalje na rodove: velike ptice, ptice plivači i ptice gnjurci (iz ptičje porodice [podreda] Gaviidae).

${ }^{10}$ Najbrojniji red na prostoru RH s brojnim rodovima. Podjela vrapčarki na rodove nije konačno definirana jer zoolozi vrapčarke dijele na dva reda: 1) kreštalice (mravarice, kosci, lončarice i dr.) i 2) pjevice (ševe, brljci, zebe, lastavice, vrapci, grmuše i dr.) (Krnjeta, 2003).

${ }^{11}$ Bogatstvo se hrvatske ornitofaune najviše ogleda u tzv. gnjezdaricama. Bilježi se gniježđenje 243 roda, a najveći je broj gnjezdarica među vrapčarkama (Passeriformes) i sokolovkama (Falconiformes), gdje dominira šljukarica (Charadriformes). 


\section{2. Čestotnost ptičjih vrsta kao podloga korpusa ornitonimskih prezimena}

Prema monitoringu ptica koje obitavaju na prostoru Republike Hrvatske dostupan je popis čestih vrsta ptica na području $\mathrm{RH}^{12}$. Taj je važan dokument, uz prezimena preuzeta iz zadnjega popisa stanovništva 2011. godine $^{13}$, poslužio kao podloga za izradu istraživačkoga korpusa ornitonimskih prezimena. Popis čestih ptica donosi podatke o pedeset ptičjih naziva s prostora $\mathrm{RH}$, a koje su:

cvrčak, čaplja, čavka, češljugar, čiopa, čižak, čvorak, ćuk, djetlić, drozd, fazan, galeb, gavran, gnjurac, golub, grlica, grmuša, gugutica, guska, jarebica, jastreb, kobac, kokoš, kos, kraljić, kukavica, labud, lastavica, orao, patka, piljak, prepelica, pupavac, roda, sjenica, slavuj, sokol, svilore0pa, svraka, ševa, škanjac, šljuka, trčka, vivak, voljak, voljić, vrabac, vrana, zeba i žuna.

Neke su od njih više, a neke su manje prepoznatljive. Kao primjer te prepoznatljivosti iz popisa su čestih ptica izabrane sljedeće klasificirane za potrebe ovoga rada kao ptičji apelativi, koje su: ptica i uz nju četiri vrste gavran, golub, sokol i vrana. Na osnovi je (samo) tih pet apelativa izrađen probni/pokusni korpus, preuzimanjem prezimena iz dostupnoga popisa stanovništva RH (2011) kako slijedi:

1) ptica: Ptićak, Ptičar, Ptićek, Ptić, Tica, Tich, Ticl, Tičak, Tičarić, Tičić, Tićina, Tičinović, Tić, Tićac, Tićak;

2) gavran: Gavran, Gavrančić, Gavranić, Gavranović, Gavrić, Gavrilov, Gavrilović, Gavron, Havran, Havranek, Kavran;

3) golub: Galab, Galobić, Galombaš, Galub, Golub, Goluban, Golubar, Golubič, Golubiček, Golubičić, Golubić, Golubov, Golubovac, Golubović, Holub, Holubek;

4) sokol: Sokol, Sokola, Sokolaj, Sokolar, Sokoli, Sokolić, Sokolov, Sokolović, Sokolovski;

${ }^{12}$ Popis je najbrojnijih ptičjih rodova izrađen prema Izvještaju o monitoringu ptica u RH za 2016. godinu, a na: http://www.haop.hr/sites/default/files/uploads/dokumenti/03_prirodne/ monitoring_prog/ceste\%20vrste\%20ptica.pdf. 13.10.2020.

${ }^{13}$ Popis je zabilježenih prezimena u RH iz 2011. godine dostupan u formatu Excel, a za potrebe je istraživanja u ovome radu preuzet s: https://www.mirovina.hr/novosti/provjeritepopis-33-000-prezimena-saznajte-koliko-ih-hrvatskoj-nosi-vase/. 8.10.2020. 
5) vrana: Vrana, Vranar, Vranaričić, Vrančić, Vrandečić, Vrane, Vranek, Vraneković, Vraneš, Vraneša, Vranešević, Vranešić, Vranetić, Vraničar, Vraničić, Vranić, Vranka, Vrankić, Vranko, Vrankovečki, Vranković, Vrankulj, Vranović, Vranjković.

Prema ovakvoj probnoj podjeli stvoreni su uvjeti za daljnju izradu popisa ornitonimskih prezimena, prema kriteriju vidljivosti apelativa koji je vezan uz ptičji svijet. Pokazalo se ovakvim pristupom da je izrada istraživačkoga korpusa izvediva kroz ciljano traženje i vidljivost tzv. ptičjega apelativa u popisu nešto više od trideset i tri tisuće zabilježenih prezimena na prostoru Republike Hrvatske (2011).

\section{Apelativ - osnova u korpusu ornitonimskih prezimena}

Izdvajanjem prezimena s ornitonimom u sastavu izrađena je baza. Detaljnim je pregledom zadnjega popisa stanovništva Republike Hrvatske (2011) dobiven zaokružen popis prema vidljivosti motivirajućega apelativa. Iščitava se on iz prezimenske osnove i u vezi je sa svijetom i životom ptice (cf. Frančić, 2019, 58). Izdvojena su tako prezimena koja u sastavu imaju ptičji naziv ili vrstu. Slična su ostalim prezimenima po tomu što imenovatelj zahvaća vrelo apelativnoga (ovdje konkretno ptičjega). Iz apelativa se iščitava kroz osam motivacijskih modela konačan lik prezimena. Klasifikacija je modelirana prema obilježju apelativa iščitanoga iz prezimenskoga lika kako slijedi u nastavku:

1) apelativnoj se osnovi dodaje sufiks i višesložni sufiksi iz standardnoga jezika (-ac, -ak, -čić, -ić, -ica, -ović, -ovčić, -ovski);

2) apelativnoj se osnovi dodaje sufiks karakterističan za dijalekatski obilježena hrvatska prezimena (-ec, $-e k,-i n,-o v)$;

3) transonimizacija kojom je apelativ onimiziran bez dodavanja sufiksa (kokoš, kokot, gavran, golub, lastavica, pijevac, sokol, sova i dr.);

4) apelativ je stranoga podrijetla (fink, štiglić, grdelin i dr.);

5) apelativ je dijalekatski obilježen (čuča, ćuran, koka, kopun, pevec, picek, pivac, raca, rebac, škrlec, štrk, tić, tuka i dr.);

6) apelativ je metaforički i metonimijski pojam iz svijeta (i izgleda) ptica (kandža, kljun, krilo, pandža, perje, pjev, kreštanje, pijukanje i dr.);

7) apelativ je zanimanje (ptičar, golubar, kokošar, pilićar, sokolar i dr.); 
8) apelativ je amblemsko-heraldičkoga značenja (gavran, jarebica, orao, sokol i dr.).

Prema podjeli u osam skupina, a prema kriteriju vidljivosti i značenju tzv. ptičjega apelativa, nemoguće je izvesti jedinstvena razgraničenja, pa je na nizu primjera jasno preklapanje jednoga apelativa u više skupina ${ }^{14}$. O preklapanju se unutar više skupina neće dalje raspravljati budući da je cilj rada usmjeren na predstavljanje prezimena s nazivom za pticu kao komponentom, ornitonimom kao sastavnicom. Preklapanja su brojna jer jedno prezime može istodobno biti unutar više motivacijskih modela, promatrani apelativ može istodobno biti odraz dijalekatskih posebitosti i stranih utjecaja u postupku nastanka prezimena (grdelin), neki su apelativi pak istodobno značenjem metafore iz života i zanimanja ljudi (kokošar), a ponekad je nemoguće jednoznačno odrediti inicijalni apelativ, odnosno onim (vrana i muško ime Franjo/Frane) ${ }^{15}$. Iz navedenih je preklapanja jasno kako jedan apelativ ima višestruki motivacijski učinak pri stvaranju konačnoga prezimenskoga lika.

Za potrebe je razmještanja prezimena u osam apelativnih skupina korišten kriterij jasnoće i prozirnosti apelativa (ili apelativne osnove) koji je, dakako, usko vezan i dio je svijeta i života ptica. Na taj je način izdvojeno iz popisa prezimena na prostoru Republike Hrvatske (2011) skoro tri stotine prezimena opisanih, poredanih i obrađenih unutar osam skupina prema kriteriju jasnoće i vidljivosti tzv. ptičjega apelativa.

\section{Prezimena prema vidljivosti (i značenju) ptičjega apelativa}

Zadani okvir unutar kojega se postavlja prezime s ornitonimom u sastavu jest apelativ koji je dio ili je vezan uz svijet ptica. Po tome je apelativu

\footnotetext{
${ }^{14}$ Svako je prezime simbioza riječi i povijesnoga čina gdje se pri konačnome stvaranju do konačnoga oblika (iz)gubi leksički orijentir temeljem kojega je prezime postalo. Promatrana prezimena tada postaju etimološki neprozirna i tvorbeno nejasna te je jedini kriterij za otkrivanje etioloških (uzročnih) činjenica u postanku prezimena geneologija prezimena na određenome geografskome području u uokvirenome vremenskome razdoblju (cf. Vekarić, 2003, 549-552).

${ }^{15}$ Ponekad je nemoguće odrediti je li današnji prezimenski lik iniciran od imenice vrana ili je od muškoga imena Frano u prezimenima Vranić, Vrančić ili Vranković. Inače je ova skupina prezimena jedna od najbrojnijih.
} 
iz života i svijeta ptica uspostavljeno osam skupina. U nekima je od njih veći broj popisanih prezimena, neke skupine su sa svega nekoliko primjera prezimena, ali dovoljno da bi se uspostavila klasifikacija prezimena koja je postankom vezana uz ptice i ptičji svijet. Donose se u nastavku uspostavljene skupine, opisane su i svaka je ovjerena kroz primjere hrvatskih prezimena zatečenih na prostoru Republike Hrvatske na posljednjemu popisu stanovništva iz 2011. godine.

\subsection{Apelativ (ili apelativna osnova) sa standardnim sufiksom u prezimenu}

Hrvatski standardni jezik bilježi brojne sufikse koji se javljaju i u hrvatskim prezimenima (v. Barić et al., 1997, 330), a među najčešćima su sljedeći: $-a c,-a k,-c ̌ c i c ́,-i c ́,-i c a$ te brojni tzv. prošireni sufiksi ${ }^{16}$ koji se dodaju središnjemu sufiksu kao što su -elj-ev-ić, -ev-ić, -ov-čič, -ov-ić, -ov-ski. I u jednome i u drugome slučaju dodavanjem sufiksa na apelativnu osnovu, koja je iz svijeta ptica, vidljivi su brojni konačni oblici prezimenskih likova, a prema sufiksu ili proširenim sufiksima to su:

-ac: Pivac, Slavujac, Ševerac, Tičac, Tićac, Žunac;

-ak: Kljunak, Ptičak, Sračak;

-an: Goluban, Kreštan, Perjan;

-ar: Golubar, Kardianar, Picukar, Ptičar, Sokolar, Vraničar;

-čić: Gavrančić, Golubičić, Sračić, Tičić, Žunčić;

-čki: Rački;

-elj: Ševelj, Vrabelj;

-elj-ev-ić: Ševeljević;

-ev-ić: Perjević, Pivčević, Štrkljević, Vrabčević;

-ica: Kreštalica, Piplica, Pivalica, Pjevalica;

-ić: Gavranić, Gavrić, Golubić, Gusić, Kardašić, Kokić, Kokotić, Kopunić, Kreštić

-ov-čič: Lastovčić, Orlovčić;

${ }^{16}$ Proširene sufikse u prezimenima Šimunović $(1997,153)$ objašnjava kao najčešće dvosložne ili trosložne sufikse sastavljene od: 1) posvojnoga elementa (-elj, -ev, -ov) i 2) oznake za mlado (-ić). 
-ov-ić: Ćurković, Gavranović, Gavrilović, Golubović, Gusković, Kokanović;

-ov-ski: Orlovski, Sokolovski.

\subsection{Apelativ (ili osnova) sa sufiksom dijalekatski obilježenih hrvatskih prezimena}

Brojna su hrvatska prezimena koja imaju dijalekatska obilježja (o ornitonimima iz čakavskoga detaljno u Filipi 2013, 149-162) s obzirom na sufiks tipičan za pojedini dijalekt (Finka, 1978, 57-58). U nizu je primjerice srednjodalmatinskih uzmorskih govora s takvim obilježjem skupina prezimena sa sufiksom -in ili -ov. Za brojne su pak kontinentalne govore, a koji su često geografski određeni unutar nekih od kajkavskih govora, karakteristični u prezimenima sufiksi -ec ili -ek, a i sufiksi -eš i -oš, koji upućuje na izravan mađarski utjecaj. Zanimljiv je u ovoj motivacijskoj skupini sufiks -er jer upućuje na germanski utjecaj pri postanku prezimena gdje se na proziran hrvatski (ptičji) apelativ dodaje strani sufiks. Istaknut je unutar skupine i sufiks -ulj, koji u dosadašnjoj jezikoslovnoj literaturi nije dovoljno opisan, a zastupljen je u brojnim govorima ${ }^{17}$. Ovu skupinu karakteriziraju sufiksi zabilježeni u prezimenima, a karakteristični za pojedini hrvatski dijalekt. Dodaje se apelativnoj osnovi (iz ptičjega svijeta i života) i tvori posebnu skupinu prezimena. Takvi su sufiksi s primjerima prezimena sljedeći:

-ec: Lastavec, Kokotec, Perjanec, Srakec, Štiglec, Zebec, Žunec;

-ek: Čuček, Golubiček, Picek, Ptićek, Rodek, Soviček, Sraček, Štrlek,

Vranek, Vrapček, Žunek;

-er: Rodiger, Štigler;

-eš: Rodeš, Vraneš;

-in: Racetin;

-oš: Kardoš, Golomboš, Patkoš;

-ov: Kardov, Golubov, Gavrilov, Orlov, Sokolov;

$-u l j$ : Sovulj.

${ }^{17} \mathrm{Uz}$ zanimljiv $-u \check{S} /-u \check{s} a$ u brojnim je hrvatskim govorima zastupljen sufiks -ulj/-ulja. Biježi se na korpusu nadimaka za ženske osobe nastalih od djevojačkoga prezimena (Bago > Bagulja, Rošćić > Roškulja i dr.). 


\subsection{Apelativ je onimiziran (transonimizacija)}

Prezimenska skupina prema kriteriju onimizacije ptičjega apelativa brojna je. U popisu je prezimena cijeli niz postalih izravnim transferom apelativa u onim. Iz svakoga se prezimena jednostavno iščitava inicijalni apelativ koji je doveo do postanka konačnoga lika prezimena. Kriterij za svrstavanje prezimena u ovaj motivacijski model je jasnoća i razumljivost apelativa koji se iščitava iz prezimena. Tako hrvatski prezimenski korpus bilježi niz prezimena nastalih procesom onimizacije iz inicijalnoga ptičjega apelativa u današnje istoliko prezime:

čavka - Čavka, čvorak ${ }^{18}$ - Čvorak, ćuk - Ćuk, drozd ${ }^{19}$ - Drozd, gavran - Gavran, golub - Golub, gusak - Gusak, guska - Guska, jarebica-Jarebica, kokoš - Kokoš, kokot-Kokot, kopun - Kopun, kos - Kos, kukavica - Kukavica, lasta - Lasta, lastavica - Lastavica, papiga - Papiga, paun - Paun, pijevac - Pijevac, ptić - Ptić, slavuj - Slavuj, sokol Sokol, sova - Sova, svraka - Svraka, ševa - Ševa ${ }^{20}$, šljuka - Šljuka, vrabac - Vrabac, vrana - Vrana, zeba - Zeba, žuna - Žuna.

\subsection{Apelativ je stranoga podrijetla}

Zbog niza je stranih jezičnih utjecaja kroz prošlost u dijelu promatranih prezimena vidljiv apelativ stranoga podrijetla (cf. Frančić, 2015, 229239). Uglavnom je taj apelativ relikt germanskoga ili romanskoga utjecaja. U skladu su s takvim utjecajem takva prezimena i geografski određena, a na način da su ona s germanskim apelativom vidljivija u kontinentalnim

${ }^{18} \mathrm{Uz}$ apelativ se čvorak (i istoliko prezime Čvorak) vezuje etimološka pripadnost niza prezimena od inicijalnoga čvorak zabilježenoga kao cvrljak, škorec, škorc, škvorc i iz njih prezimena Cvrljak, Škorec, Škorc, Škvorc. Iz ovakvih se primjera nazire preklapanje motivacijskih modela jer su pučka i dijalekatska nomenklatura dovele do miješanja više motivacija u postanku prezimena (cf. Filipi, 2013, 152).

${ }^{19}$ Apelativ je drozd i u nizu drugih prezimena, a uz Drozd, u Drozdek, Droždan, Drožđan i Drožđek.

${ }^{20}$ Niz prezimena iz inicijalnoga ševa - Ševa: Ševerac, Ševčik, Ševelj, Ševerdija, Šević, Ševo, Ševrović. I unutar ove se skupine može pojedino prezime tumačiti višeznačnom motivacijom pa je tako prezime Ševerdija moguće vezati uz glagole 1) šev(e)rdati 'lutati, vrludati; zbunjeno ili dvoznačno govoriti' i 2) ševeljati 'zanositi nogama, gegati se kao dijete', što opet dovodi u vezu s imenicom ševa. Dijalekatski su nadalje obilježeni od sinonimnoga apelativa švrljug u prezimenima Švrljug, Švrluga, Švrljuga, Švragulja. 
govorima za razliku od romanskih apelativa koji su vidljiviji u prezimenima uzmorskih govora. Korpus tako bilježi sljedeće apelative stranoga podrijetla u hrvatskim prezimenima:

1) fink (njem. fink - hrv. zeba): Fink;

2) grdelin (tal. cardellino - hrv. češljugar, grdelin): Kardašić, Kardinar, Kardo, Kardoš, Kardov, Kardum, Kardun i dr.;

3) štiglić (njem. stieglitz - hrv. češljugar): Štiglec, Štigler, Štiglić.

Promatrajući ovu motivacijsku skupinu ornitonimskih prezimena jasno je kako ptica češljugar traži zasebno jezično istraživanje s obzirom na višestrukost njezina pojavljivanja, kroz standardne, ali i kroz dijalekatski i inojezično obilježene apelative. Hrvatski jezični portal ${ }^{21}$ donosi neke od brojnih sinonima za češljugara: konopljarka, čalmašica, štiglic, štiglić, g(a)rdelin, grdelac, grdelja .

\subsection{Apelativ je dijalekatski obilježen}

Kao i u brojnim drugim apelativima, tako je i među onima koji se odnose na ptice i svijet ptica zabilježen cijeli niz dijalekatski obilježenih apelativa u strukturi prezimena. Velika je lista takvih apelativa, što govori o dinamičnome razvoju prezimenske skupine s ornitonimom u strukturi prezimena. Naravno, kako su apelativi karakteristični za hrvatske dijalekte, oni su i geografski raspoređeni u skladu s time, pa se tako u korpusu prezimena mogu iščitati dijalekatski apelativi iz svijeta ptica:

1) с̌ис̌a (stand. patka): Čuček;

2) ćuran (stand. puran): Ćurković;

3) jej / jejina (stand. ćuk, kukuvija, kukuvježa, sova, sovuljaga ${ }^{22}$ ): Jejo, Jejić;

4) $k o k a^{23}$ (stand. kokoš): Kokan, Kokanović, Kokeza, Kokić;

5) kopun (reg. uškopljeni pijetao): Kopun, Kopunić, Kopunović;

6) oreb (stand. jarebica): Oreb, Orebić;

${ }^{21}$ Cf. http://hjp.znanje.hr/index.php?show=search_by_id\&id=elplXxM\%3D. 22.10.2020.

${ }^{22}$ O leksemu jej, gen. jeja (m.) v. Skok, 1971-1974, 770 .

${ }^{23} \mathrm{U}$ standardnome je govoru hipokoristik kokica, a koka je uglavnom regionalno obilježen apelativ za manju kokoš. U govorima je srednje Dalmacije čest uz koka i oblik jednine ž. r. koke, koji je pak u današnjemu govoru dobio novo značenje kao odmilica za iskazivanje odnosa posebne bliskosti među ljudima. 
7) oroz (stand. pijetao): Oroz, Orozović;

8) pevec (stand. pijetao): Pevec;

9) picek (stand. pile, pilić): Picek $^{24}$;

10) pivac (stand. pijetao): Pivac, Pievac, Pivčević;

11) raca (stand. patka): Raca, Racanović, Racetin, Rački;

12) rebac (stand. vrabac): Rebić, Rebac ${ }^{25}$ i brabec (stand. vrabac): Brabec;

13) sraka (stand. svraka): Sraćek, Sraćić, Sraga, Sraka, Srakec, Srakić, Srakočić, Srakovčić;

14) tica (stand. ptica): Tica;

15) tić (stand. ptić, ptičica): Tić, Tičinović, Tičić, Tićac, Tićak;

16) tuka (stand. pura, purica): Tukić, Tukanić.

$\mathrm{U}$ ovoj su skupini istaknuti najreprezentativniji primjeri prezimena od dijalekatski obilježenoga ptičjega apelativa. Unutar je ove skupine moguće unositi i brojna prezimena koja se prema vidljivosti apelativa mogu kategorizirati da su postala od dijalekatski obilježenih apelativa ${ }^{26}$.

\subsection{Apelativ je metaforički i metonimijski vezan uz svijet (izgled i ponašanje) ptica}

Svaki antroponimijski sustav, pa tako i sustav prezimena, karakteriziraju metaforički i metonimijski odnosi koji su bili prisutni pri postanku

${ }^{24}$ Prezime Picukarić upućuje na sličnu apelativnu osnovu kao i Picek. To je prezime često zastupljeno na prostoru Imotske krajine i stoga je jasno kako postankom nije od picek već od picukara prema tal. pinzocchera - bogmoljka, koja se u govoru nemorskoga dijela Dalmacije bilježi oblikom picukara 1) naročito pobožna žena usidjelica i 2) časna sestra, švora (Gusić, Gusić, 2004, 319).

${ }^{25}$ Prezime se Rebić može dovesti i u vezu s pridjevom rebast 'bezrep, kusast' dok prezime Rebac pouzdano upućuje da je postankom od rebac 'vrabac', pogotovo s obzirom na geografsku rasprostranjenost prezimena Rebac po središnjoj i jugoistočnoj Hercegovini te Neretvanskoj krajini gdje je oblik rebac izrazito zastupljen u govoru.

${ }^{26}$ Samo na primjeru imenice ševa nazire se jasnoća apelativa u prezimenskim likovima Ševa, Ševerac, Ševčik, Ševelj, Ševeljević, Šever, Ševerdija, Šević, Ševo, Ševrović, ali istodobno i u prezimenima od sinonima švrljug za istu pticu u prezimenima Švrluga, Švrgulja, Švrljuga, Švragulja i dr. Zbog takvih je preklapanja velik broj prezimena ostavljen za nova istraživanja u kojima treba objasniti i opisati odnos standardnoga apelativa prema pojavnim oblicima sinonima najprije u standardu, zatim i u pojedinim dijalektima. 
konačnoga lika prezimena. Nerijetko je motivacija postanka uzrokovana aluzijama, karakternim i inim osobinama prvih nositelja prezimena, a među takvim je prezimenima i onih koja simboliziraju čovjeka kao biće usporedivo s izgledom i ponašanjem ptičjega svijeta. Hrvatski je korpus prezimena bogat primjerima metafore i metonimijskih odnosa u strukturi prezimenskih likova gdje je jasna poveznica ljudi s izgledom i ponašanjem ptica. Razlikuju se tako, s obzirom na metaforičnost i metonimičnost u motivaciji postanka pojedinoga prezimena, sljedeće odrednice:

1) metaforičnost: gugutanje: Gućéc ${ }^{27}$ ćurlikati (glas davati kao ptica): Ćurlin, kreštanje: Kreštalica, Kreštan, Kreštelica, Kreštić, pijukanje: Pijuk, Piuk, Pijuko, pjev (ptičji): Pjevalica, Pjevalo, Pjević, Pivalica; 2) metonimičnost: kandža: Kandžija, Kanđera, kljun: Klunić, Kljun, Kljunak, Kljunić, krilo: Krilanović, Kriličić, Krile, Kriletić, Krilić, pandža: Pandža, Pandžić, Panđa, Panđić, perje: Perja, Perjan, Perjanec, Perjević.

\subsection{Apelativ je zanimanje (iz svijeta ptica)}

Mada bi se prisutnost zanimanja vezanoga uz svijet ptica bolje vezala uz metonimijski odnos pri nastanku prezimena, zbog brojnosti je ,ptičjih” zanimanja u promatranim prezimenima, ova skupina zasebno popisana. Sufiks je -ar u hrvatskome jeziku vrlo plodan (cf. Babić, 1981, 141-150) u izvođenju imenica za zanimanja muških osoba. Tako je i sa skupinom zanimanja vezanih uz svijet ptica, gdje su zabilježeni sljedeći apelativi iz kojih se iščitavaju prezimena nastala prema zanimanjima:

1) ptičar: Ptičar, Ptičak, Ptičar;

2) golubar: Golubar, Golubarević, Golomboš ${ }^{28}$;

3) sokolar: Sokolarević;

4) sovar: Sovar;

5) pilićar: Pillićar, Piličić;

6) kokošar ${ }^{29}$ : Kokošarević.

${ }^{27} \mathrm{U}$ pojedinim dalmatinskim govorima bilježi se apelativ gućak - grlen i dobar glas, najčešće opis za neškolovani, ali talentirani pjevački glas.

${ }^{28} \mathrm{Na}$ području Međimurja prezime je Golomboš od mađ. galambos - hrv. golubar.

${ }^{29}$ Isti apelativ ima različita značenja: 1) zanimanje (kokošar) i 2) vrsta jastreba (kokošar). 


\subsection{Apelativ je ornitonim amblemsko-heraldičkoga značenja}

Ptica je u prošlosti često bila nositelj različitih karakteristika i simbolike. Imala je, uz niz drugih životinja, profilaktičku i zaštitničku ulogu (cf. Vajs, Brozović Rončević, 2002, 226), a prisutnost na grbovima i obilježjima neke zajednice ljudi čuvala je simbolički od nedaća i nesreća, ponekad postajala glavnim obilježjem unutar jednoga staleža, skupine ili kao glavno obilježje obiteljske ili institucionalne pripadnosti. U prezimenskome je korpusu najvidljiviji orao, zatim gavran i sokol, ali i sova i jarebica. Obilježavaju svojom vidljivošću danas niz prezimena u kojima nerijetko nose amblemsko-heraldičke oznake:

1) jastreb kraguj: Kragić, Kragl, Krago, Kragojević, Kraguj, Kragujević, Kragulj, Kraguljac ${ }^{30}$;

2) jastreb kobac: Kobac, Kobak, Kobal, Kobali, Kobaš, Kobašević, Kobašlić, Koberac, Kobeščak, Kobešćak;

3) jarebica (trčka): Jareb, Jarebica, Jarebić;

4) orao: Orle, Orlić, Orlov, Orlovac, Orlovčić, Orlović, Orlovski;

5) gavran: Gavranić, Gavranović, Gavrančić;

6) sokol: Sokola, Sokolaj, Sokolar, Sokoli, Sokolić, Sokolov, Sokolović, Sokolovski;

7) sokol škanjac: Škanić, Škantar;

8) sova: Sovar, Sovec, Soviček, Sović, Sovilj, Sovina, Sovulj.

Osam je motivacijskih skupina potvrdilo široku bazu hrvatskih prezimena. Iz njih se iščitava apelativ povezan uz svijet i život ptica. Prezimena su popisana s obzirom na značenje apelativa vidljivoga u prezimenu i, mada je u brojnim skupinama došlo do međusobnoga preklapanja, ovakva je podjela potvrdila potrebu za daljnjim proširivanjem istraživanja za postavljanje klasifikacijskoga modela za jednoznačan opis prezimena s nazivom ptice u sastavu (strukturi).

${ }^{30}$ Zanimljivost je unutar ove skupine da hrvatski prezimenski sustav ne bilježi prezime Jastreb, već su sva prezimena s vidljivošću apelativa iz podvrsta jastreba - kraguj i kobac. 


\section{Zaključak}

Ovaj je rad imao za cilj prije svega rasvijetliti teško pitanje o podjeli prezimena u čijoj se strukturi iščitava apelativ iz ptičjega svijeta. Prikupljena je prezimenska građa pokazala vitalnost ornitonima u oblikovanju hrvatskih prezimena, a sačinjeni korpus od skoro tri stotine ptičjih prezimena dao je mogućnost klasifikacije s obzirom na apelativ zastupljen u njima. Za potrebe je istraživanja bilo najvažnije izraditi valjan istraživački korpus, ali je taj postupak bio otežan zbog niza različitih, nerijetko nerazumljivih, podjela ptica u području biologije i genetike životinja. Ta je otegotna okolnost nepregledne baze vrsta, porodica, rodova i redova ptica usmjerila izradu korpusa na jedini održivi model za kasniji opis, a to je izrada korpusa koja se svela na vidljivost tzv. ptičjega apelativa u bazi hrvatskih prezimena prema popisu stanovništva iz 2011. godine. Na taj je način dobiven okvir za klasifikaciju prezimena s ornitonimom u sastavu (v. dodatak 1). Naravno, ovim je radom samo potaknuto istraživanje prezimena koja u strukturi imaju/kriju ptičji svijet. Put je do konačnoga oblikovanja korpusa ptičjih prezimena dug, ali istodobno izazovan, s nizom pitanja otvorenih upravo ovim istraživanjem. Ptica će, jasno je, kao i do sada ostati važna spona u trajnoj vezi čovjeka i prirode. Time ona ostaje zanimljiva i privlačna kao tema jezičnih istraživanja jer su brojne vrste i rodovi, čestotnost u prirodi, ptičji fond apelativa, preklapanja više motivacija, povijesna, geografska i kulturna uvjetovanost naziva pojedine vrste ptice, njegova metaforičnost i metonimičnost samo manji dio od niza područja za dublja i šira istraživanja. $\mathrm{S}$ druge pak strane, brojne su ptičje vrste, podvrste, skupine i podskupine poput gregule, grlice, čiška, fazana, vivka, voljka, zatim brojni piljci, grmuše i kraljići ostali tek usput spomenuti do dobivanja svoga opisa u budućim jezikoslovnim istraživanjima.

\section{Literatura}

Babić, S. (1981). Tvorba imenica sufiksima na -ar. „Filologija” br. 10, str. 141-150. Barić, E. et al. (1997). Hrvatska gramatika. Zagreb: Školska knjiga.

Batašić, B. (2012). Značajke ptica Hrvatske. [Neobjavljeni seminarski rad]. Zagreb: Prirodoslovno-matematički fakultet Sveučilišta u Zagrebu.

Filipi, G. (2013). Ornitonimi posuđeni iz čakavskih govora u istromletačkom iz Istromletačkog lingvističkog atlasa (ImLA). „Hrvatski dijalektološki zbornik” 18, str. 149-162. 
Finka, B. (1978). Košarkaši Jerkov i Grgin u jezičnoj retorti. „Jezik” god. 26, br. 2, str. $57-58$.

Frančić, A. (2015). Odslik hrvatsko-mađarskih dodira u hrvatskim prezimenima. „Linguistica" br. 55, str. 229-239. https://doi.org/10.4312/linguistica.55.1.229-239.

Frančić, A. (2019). Geolingvistika i antroponomastička istraživanja: prezimena od naziva za osobu koja kroji i šije odjeću. „Hrvatski dijalektološki zbornik” br. 23, str. 55-80. https://doi.org/10.21857/mnlqgc056y.

Gusić, I., Gusić, F. (2004). Rječnik govora dalmatinske Zagore i zapadne Hercegovine. Zagreb: Vlastita naklada.

Krnjeta, D. (2003). Ptice Hrvatske: Ornitološki priručnik. Zagreb: Meridijani.

Lukač, G. (2007). Popis ptica Hrvatske. „Natura Croatica” god. 16, br. 1, str. 1-148.

Putanec, V., Šimunović, P. (ur.). (1976). Leksik prezimena Socijalističke Republike Hrvatske. Zagreb: Institut za jezik-Nakladni zavod Matice hrvatske.

Skok, P. (1971-1974). Etimologijski rječnik hrvatskoga ili srpskoga jezika, I-II. Zagreb: JAZU.

Šimunović, P. (1997). Die Charakteristika der kroatischen Familiennamen. „Folia onomastica Croatica" br. 6, str. 147-157.

Šimunović, P. (2006). Hrvatska prezimena. Zagreb: Golden marketing-Tehnička knjiga.

Vajs, N., Brozović Rončević, D. (2002). Zoonimi u hrvatskim prezimenima. „Folia onomastica Croatica" br. 11, str. 223-238.

Vekarić, N. (2003). Genealogija u službi onomastike. „Folia onomastica Croatica” br. $12 / 13$, str. 549-552.

\section{Dodatak 1. Baza hrvatskih prezimena s ornitonimom}

Abecedni popis hrvatskih prezimena s ornitonimom u sastavu/sadržaju/strukturi

B Brabec

Č Čavka, Čavkić, Čuček, Čvorak

Ć Ćuk, Ćurković

D Drozd, Drozdek, Droždan, Drožđan, Drožđek

F Fink, Finka, Finkulja

G Gavran, Gavrančić, Gavranić, Gavranović, Gavrić, Gavrilov, Gavrilović, Gavron, Golomboš, Golub, Goluban, Golubar, Golubiček, Golubičić, Golubić, Golubov, Golubovac, Golubović, Grlica, Grmuša, Guć, Gućanac, Gusak, Gusić, Guska, Guskić, Gusković

H Havranek, Havranić

J Jareb, Jarebica, Jarebić, Jejić 
K Kandžija, Kanđera, Kardašić, Kardinar, Kardo, Kardoš, Kardov, Kardum, Kardun, Klunić, Kljun, Kljunak, Kljunić, Kobac, Kobak, Kobal, Kobali, Kobaš, Kobašević, Kobašlić, Koberac, Kobeščak, Kobešćak, Kokan, Kokanović, Kokeza, Kokić, Kokorović, Kokoš, Kokošarević, Kokoška, Kokot, Kokotec, Kokotić, Kokotović, Kopun, Kopunić, Kopunović, Kos, Kragić, Kragl, Krago, Kragojević, Kraguj, Kragujević, Kragulj, Kraguljac, Kreštalica, Kreštan, Kreštelica, Kreštić, Krilanović, Krile, Kriletić, Kriličić, Krilić, Kukavica

L Lasta, Lastavec, Lastavica, Lastovčić

O Oreb, Orebić, Orle, Orlić, Orlov, Orlovac, Orlovčić, Orlović, Orlovski

P Pandža, Pandžić, Panđa, Panđić, Papiga, Papuga, Patkoš, Patković, Paun, Paunić, Paunović, Perja, Perjan, Perjanec, Perjević, Pevec, Picek, Picukar, Picukarić, Pievac, Pijetlović, Pijevac, Pijević, Pijuk, Pijuko, Piplica, Piuk, Pivac, Pivalica, Pivčević, Pjevalica, Pjevalo, Pjević, Ptičak, Ptičar, Ptić, Ptićak, Ptićek

R Raca, Racanović, Racetin, Rački, Rebac, Rebić, Rode, Rodek, Rodela, Rodeš, Rodi, Rodić, Rodiger, Rodik, Rodin

S Slavuj, Slavujac, Slavujević, Slavulj, Slavuljica, Sokol, Sokola, Sokolaj, Sokolar, Sokoli, Sokolić, Sokolov, Sokolović, Sokolovski, Sova, Sovar, Sovec, Soviček, Sović, Sovilj, Sovina, Sovulj, Sraček, Sračić, Sraćek, Sraćić, Sraga, Sraka, Srakec, Srakić, Srakočić, Srakovčić, Svračak, Svraka, Svrakić

Š Ševa, Ševarac, Ševčik, Ševelj, Ševeljević, Škanić, Škantar, Šljuka, Šljukić, Štiglec, Štigler, Štiglić, Štrk, Štrkalj, Štrkljević, Štrkonjić, Štrković, Štrlek, Štrljić, Švragulja, Švrluga, Švrljug, Švrljuga

T Tica, Tich, Ticl, Tičac, Tičak, Tičarić, Tičić, Tičić, Tičinović, Tić, Tićac, Tićak, Tićina, Tićinović, Tukanić, Tukić

V Vrabac, Vrabač, Vrabčević, Vrabec, Vrabel, Vrabelj, Vrabić, Vrana, Vranar, Vranaričić, Vrančić, Vrančić, Vrandečić, Vrane, Vranek, Vraneković, Vraneš, Vraneša, Vranešević, Vranešić, Vranetić, Vraničar, Vraničić, Vranić, Vranka, Vrankić, Vranko, Vrankovečki, Vranković, Vrankulj, Vranović, Vranjković, Vrapček, Vrapčenjak, Vrapčević, Vrebac, Vrebalov

Z Zeba, Zebec, Zebić

Ž Žun, Žuna, Žunabović, Žunac, Žunar, Žunčić, Žunec, Žunek, Žunić, Žunko 